\title{
Effect of Financial Leverage on Profitability of Firms Listed in the Nairobi Securities Exchange
}

\author{
Margaret Olang' \\ Department of Business Administration, Chuka University
}

\begin{abstract}
Financial leverage is the use of fixed charge sources of funds to finance the firms' investment projects. A levered firm is a firm that employs debt in its capital structure. Excessive use of debt is likely to expose the firm to financial risk hence insolvency. Therefore, a firm should maintain an optimal capital structure that will minimise the overall cost of capital. This study sought to establish the effect of financial leverage on the profitability of firms listed in the NSE. Causal research design was employed on the target population of 66 listed firms. Purposive sampling technique was used to select a sample size of 30 listed firms. Data was analysed using descriptive and inferential statistics. Descriptive statistics was used to test for normality of data. Inferential statistics on the data were done using regression model. The study established that, firm size has a statistically significant effect on the profitability of listed firms with $p$ value of 0.002. Liquidity and growth opportunity on the other hand were not statistically significant indicating $p$ values of 0.062 and 0.914 respectively. This means they have no significant effect on the profitability of firms listed in the NSE.
\end{abstract}

Keywords: Leverage, Liquidity, Firm's growth, Firm size, Insolvency

\section{Introduction}

Financial leverage is the existence of debt in the capital structure of a firm [17]. It is linked with various variables but for the purpose of this study it will be considered in terms of liquidity, firm size and growth opportunities for a firm. According to [6] profitability is the effectiveness of management in generating profits with its available assets. Profitability, apart from being an indication of a firm's financial performance it is also in line with the shareholders wealth maximization goal of the firm.

Various studies have been conducted to analyse the effect of financial leverage variables on the profitability of firms. Liquidity affects the profitability of firms due to the fact that holding too much liquidity leads to the firm suffering opportunity cost of holding cash thus affecting its profit making capacity. On the other hand, if the firm is liquid enough to meet its current obligations as they fall due it would not end up incurring high costs to pay the accumulated liabilities. Therefore, the profitability of the firm will not be adversely affected by its liquidity level. Firm size is the amount and variety of production capacity and ability firm possesses or the amount and variety of services a firm can provide concurrently to its customers. Due to the concept of economies of scale firm size is inclined with the profitability of firms. Growth opportunity also has some effect on the profitability of firms. Growth opportunity may cause the demand to raise extra finance to carter for the increase in operations. A firm might therefore seek external sources of financing. If the firm invests in projects that are viable, that is they promise NPVs of more than zero, this means that the expected cash flows from the project will exceed the initial cost of investing and the project might be profitable holding other factors constant. It is evident that in one way or another, the variables affect the profitability of a firm.

Nairobi Securities Exchange was facilitated by the birth of the Companies Act 1948 (Cap 486), initially as Nairobi Stock Exchange, that came into existence in 1954. The NSE is regulated by the CMA and its main function is to provide a stock market where shares are bought and sold. NSE helps in the transfer of savings to investment in productive ventures rather than keeping the savings idle, this helps in cultivating a saving culture in both local and foreign investors. Several companies are listed under the NSE this means that the shares of this companies are traded in this market. The firms are both financial and non-financial and are grouped under various sectors. These sectors are agricultural, automobiles and accessories, banking, commercial and services, construction and allied energy and petroleum, insurance and investment sectors.

\section{Literature Survey}

\section{Financial Leverage}

Financial leverage is the composition of debt in the capital structure of a firm. A firm that uses financial leverage is said to be trading on equity. The higher the amount of debt employed by a firm the higher its financial leverage. A higher degree of financial leverage means high interest payments which negatively affect the company's bottomline earnings per share. High financial leverage also increases financial risk to shareholders threatening the returns they expect from their investments. It is affected by various factors such as company size, company age, liquidity, tangibility of asset, non-debt tax shield, and growth opportunity among others. Financial leverage is an important area of interest since it has an effect on profitability of a business entity. For the purposes of achieving the objectives of this study, financial leverage will be consider in terms of liquidity, firm size and growth opportunity determining their effects on the profitability of firms listed in the NSE.

\section{Liquidity}

Liquidity is indicated by a firm's ability to meet its short term obligations as they fall due. This includes obligations that mature within a period of one year and expenses of the firms operating cycle. It is computed by dividing current assets with the current liabilities. When a firm cannot meet 


\section{International Journal of Science and Research (IJSR) \\ ISSN (Online): 2319-7064}

Index Copernicus Value (2015): 78.96 | Impact Factor (2015): 6.391

its current obligations it is said to be illiquid. Liquidity management can be achieved by managing assets, current liabilities and long term funds. When a firm is limited in terms of liquidity it will not be able to meet the short term obligations and will opt to borrow for that purpose. However, due to the asset composition it is likely that the cost of the borrowed funds will be high. This is because the financial institutions advancing credit will evaluate the firm as risky in terms of payment of the debt. By not having sufficient cash or liquid assets a firm might be forced to sell some of its asset on short notice to meet its obligation. This places the firm on the verge of suffering losses on sale of assets since it may be forced to sell the assets on at a fire sell price. Retaining too much liquidity means the firm will not invest in other projects that suffer the opportunity cost of holding cash. In both the above cases the profitability of a firm will be affected negatively. According to [5] there is a significant negative relationship between a firm's profitability and its liquidity level. Liquidity= Current Assets/Current Liabilities.

\section{Firm Size}

[17] Defines firm size as the total number of assets held by an organization. Firm size is important in determining the profitability of firms. A larger firm has a greater influence on shareholders financial institutions and the general public. Large firms are not likely to face bankruptcy this puts the firms in a position to easily acquire debt finance since they are presumed to have the capacity of meeting up the interest payments. They also have a higher capacity to provide collateral securities for acquiring debt finance. Large firms are also well diversified thus having a wider scale of operations compared to smaller firms and enjoy a wider access to market information. With all the above considerations the adoption of financial leverage is expected to automatically improve performance of the firms in this case increase the profits. Smaller firms on the other hand are restricted in terms of scale of operations, diversification and access to market information. This creates a challenge in acquiring external funds from investors and financial institutions that are afraid of committing their funds in smaller projects. The smaller firms also by using financial leverage may be exposing themselves to risks associated with distress, bankruptcy as well as loss of ownership. Thus, the size of a firm determines its profitability. Firm Size=In of Total Assets.

\section{Growth Opportunity}

Growth opportunity is composed of capital assets which add value to the firm but cannot be collateralized and do not generate taxable income. Growth opportunity open up the firm to the option of seeking external financing in case the internal finance is not enough to meet the increase in operating expenses that come with the growth. Consequently, this allows the firm to venture into various projects. The returns from the project will in turn affect the profitability of the firm. If the projects earn positive NPVs then the project is viable and would earn the firm profits. This may be the case for small and growing firms. Considering a large firm that has been in existence for a long period of time growth opportunity may have little or no effect on its profitability. Larger firms become competent over time and there is lesser room for further improvement in these firms in terms of growth and profitability, leading to a random process of growth, especially among large firms. Growth Opportunity=Annual percentage change in Total Assets.

\section{Profitability}

Profitability can be defined as the ability of a firm to earn profits. Although closely related, profitability and profit are different concepts. Profits are the funds that remain after a firm has settled all its expenses and are useful in refinancing its operations. Therefore, if a firm has enough profits it may not have to seek external finance. Profitable firms can also obtain debt at a lower interest rate since they are viewed as less risky. However, high profit is not an indication of organizational efficiency. Profitability measures productivity of capital employed and operational efficiency of a firm. Profitability is an overall measure of a firm's economic success and the competence of its management. Low profitability is not an indication of organizational sickness. This study will measure profitability using Return on Assets which measures productivity of capital employed. Return on Assets =Profit after Tax/Total Assets.

\section{Theoretical Framework}

This portion covers theories that are relevant to financial leverage so that to get a deeper knowledge and understanding of the concept. The theories considered are Modigliani and Miller, Pecking order theory, Trade-off theory and Agency cost theory.

\section{Modigliani and Miller}

According to Modigliani and Miller, in the absence of taxes, transaction costs and an efficient market the value of the firm is unaffected by its financing. Modigliani and Miller theorem is often referred to as capital structure irrelevance principal. Whether a firm is highly leveraged or has lower debt component in the financing mix, it has no bearing in the value of the firm [8]. The theorem further indicates that the market value of a firm is affected by its future growth prospects apart from the risk involved in investments. The theorem however lacks credibility since no firm operates in a market without taxes and transaction costs.

Due to the criticisms of their first proposition Modigliani and Miller came up with another proposition. Under this proposition they maintained that financial leverage is irrelevant with financial performance and if taxes and other costs occur, then the two factors to be considered are the weighted average cost of capital and the cost of equity. The WACC increases with increase in debt and the firm's shareholders will demand a higher cost of equity when debt increases due to the possibility of the firm being bankrupt from the high debt. Modigliani and Miller under proposition one and two conclude that under the stated assumptions capital structure has no effect on the profitability of firms.

\section{Pecking Order Theory}

This theory was first stipulated by Donaldson in 1961. It was modified by Stewart C Myers and Nicolas Majluf in 1984. The theory states that firms prioritize their sources of finance (from internal financing to equity) according to the cost of capital, preferring to raise equity as financing means of last resort. Internal funds are first used and when depleted 


\section{International Journal of Science and Research (IJSR) \\ ISSN (Online): 2319-7064}

Index Copernicus Value (2015): 78.96 | Impact Factor (2015): 6.391

debt is issued. The theory is based on the concept of asymmetric of information as managers know more about their firms' prospects, risk and value than outside investors. The access to this information affects the choice between internal and external financing thus the existence of a pecking order for the financing of new projects. The theory is supported by the perception that firms only issue equity share when in financial trouble making managers to avoid issuance of equity as much as possible. This theory suggests that debt has a positive effect on profitability of firms.

\section{Trade-off Theory}

This theory which was stipulated by Myers in 2001 is based on the idea that a firm chooses how much debt finance and equity to use by balancing costs and benefits. It considers the balance between the dead-weight costs of bankruptcy that come with use of high debt and the tax shield benefits of debt. Agency costs are also included in the balancing. Debt offers a tax shield and firms therefore pursue high debt levels in order to gain the maximum tax benefits that ultimately enhance profitability. According to this theory debt financing is good when optimized. However maintaining an optimum debt level may prove difficult in the face of adverse changes in the operating environment of the firm. This theory indicates that debt has a negative effect on profitability if not optimized.

\section{Agency Theory}

The theory highlights the conflict of interest between management and the owners of the firm in this case the shareholders. This arises when the management pursue its own interests rather than the interests of the owners of the business. The theory argues that managers act in their own interests such as job security and prerequisites. [7]Argues that the problem is how to motivate managers to disgorge the cash rather than investing below the cost of capital or washing it away on organizations inefficiencies. The theory then suggests that to deal with this problem a firm should employ debt for this would limit the firms' spending in order to avoid default risk. Thus usage of debt has a positive effect on profitability.

\section{Empirical Review}

This portion outlines various studies on the effect of leverage on profitability and other aspects of a firm. It comprises of studies from different sectors and different economies both local and international. The studies are also from different periods. It looks into the findings of the different studies.

[2]Conducted a study on the relationship between capital structure and banking performance in Pakistan. They used data from banks listed in the Pakistan stock exchange for the period from 2007 to 2011. They used multiple regression model to establish the relationship between capital structure and banking performance. They found a positive relationship between debt financing and banks profitability.

[18] Studied the impact of capital structure on financial performance of firms listed in the Tehran Stock Exchange. They used as sample of 40 firms among the firms listed. The results from their study suggested that there is a significant negative relationship between debt ratio and financial performance. They also concluded that there is a significant positive relationship between asset turnover, firm size, and assets tangibility and growth opportunity with financial performance.

[1] Conducted a research on the effect of financial leverage on the profitability of firms in the fuel and energy sector in Pakistan. From there findings they concluded that financial leverage has a positive impact on the profitability of firms.

[15] Studied the impact of financial leverage on financial performance. The study was conducted on 30 non-financial institution listed in the Nigeria Stock Exchange. Based on their findings they concluded that debt ratio which was used to measure financial leverage has a negative effect on the profitability ratios, which are Return on Assets and Return on Equity.

A research by [20] has shown non-significant relationship between debt to total assets ratio and Return on Assets ratio. His study was on the effect of capital structure on profitability of firms drawing evidence from Kenya's the banking sector. He used data from banks listed in the NSE for the period 2004-2012. He used panel data analysis to analyse the data.

[13] Examined the relationship between leverage and financial performance of forms listed in the NSE. The study used descriptive research design. It used both primary data from interviews and secondary data from annual financial statements of the listed firms. Data analysis was done using SPSS and presented in pie charts, graphs and tables. The conclusion of the study was that financial leverage did not contribute to financial performance of firms listed in the NSE.

From the literature review, most theories have indicated that financial leverage has a positive effect on the profitability of firms less for the Modigliani and Miller propositions one and two which has unrealistic assumptions since no firm can operate in a market with no taxes, no transaction costs and which is efficient. The analysis of empirical review revealed that some studies are in line with the theories for example [2] concluded that financial leverage has a positive effect on profitability of firms. However, some studies contradict with the theories. For example [18] and [13] concluded that financial leverage has a negative effect on the profitability of firms. A study by [20] found no significant relationship between capital structure and firms profitability which was in line with Modigliani and Miller (1958) capital structure irrelevance principal. This contradictions and variations indicate the need to determine the effect of financial leverage on the profitability of firms listed in the NSE.

\section{Problem Definition}

Financial leverage is the use of fixed-charge funds such as debt and preference capital along with the owners' equity in the capital structure [4]. Ideally, the means a firm uses to raise funds for financing purposes should be such that the profits obtained from the investment exceed the cost of funds used in financing the investment. Financial leverage thus aims at reducing the cost of capital so as to improve on the profitability of a firm. Financial leverage allows a 


\section{International Journal of Science and Research (IJSR) \\ ISSN (Online): 2319-7064}

Index Copernicus Value (2015): 78.96 | Impact Factor (2015): 6.391

potentially high return for a firm but it also comes with the potential of a great loss. This is the case when the investment does not perform well and yet the leveraged funds need to be paid; both the principal amount and the interest charged on the debt. Using debt finance beyond a certain level possess a financial risk to the firm. The higher the amount of debt used, the higher the level of the financial risk. In extreme cases some firms have been declared insolvent which means they are unable to pay the debt finance used in investing. Too much debt has led to delayed payments of interest and principal thus reduction in the current assets of a firm. Also if a firm does not earn profits it ends up illiquid thus unable to finance its current obligations. It is therefore very important to consider the effect of financial leverage on the profitability of firms listed in the NSE.

\section{Methodology}

This section contains the research methodology to be used in order to attain the objectives of the study. 4

\section{Research Design}

The study adopted causal research design which involves the investigation of cause-and-effect relationships. According to [3] causal research design shows the relationship between variables.

\section{Target Population}

A target population is the specific group that a particular study is interested in researching on. The population of this study was made up of all the 66 firms listed in the NSE. The firms are grouped in different sectors.

\section{Sampling Procedure and Sample Size}

Purposive sampling technique was adopted. This is because the technique allowed the researcher to select 30 firms whose financial statements were available during the period under study. The firms in the banking and insurance sectors were not put into consideration since their main regulators are the $\mathrm{CBK}$ and IRA respectively who regulate their use of leverage.

\section{Data Collection}

The study used secondary data which was provided in the financial statements of the sample firms as provided in the NSE handbook and their individual financial statements. Specifically, from the statement of financial position the study was interested in the Profits after Tax, Current Assets, Current Liabilities and the Total Assets. The data was collected for the period 2010-2015.

\section{Data Analysis}

The data was collected, cleaned, edited, coded and fed into excel before being imported to SPSS version 16.0 for analysis. Descriptive statistics was used in terms of mean, standard deviation, frequency, percentages, mode and median. Inferential statistics was also used to draw inferences about the cause effect relationship between financial leverage and profitability of firms by the use of a regression model.

\section{Regression Model}

The following regression model was developed for the purpose of this study .

$\mathrm{Y}=\mathrm{a}+\beta_{1} \mathrm{LI}+\beta_{2} \mathrm{FM}+\beta_{3} \mathrm{GO}+\mathrm{e}$

$\mathrm{Y}=$ Profitability which was measured using return on assets.

(Profit after Tax/Total Assets).

$\mathrm{a}=$ constant

$\beta 1, \beta 2, \beta 3=$ Regression coefficients.

LI=Liquidity which was measured using current ratio.

(Current Assets/Current Liabilities).

FM= Firm size which was measured using

$\mathrm{GO}=$ Growth opportunities was measured using annual percentage change in total assets.

$\mathrm{e}=$ Error term.

\section{Results and Discussion}

This section contains analysis, presentation of findings and results.

\section{Correlation Analysis}

Correlation is the existence of relationship between the independent variables and the dependent variable. The study sought to determine the magnitude of relationship between each independent variable and the dependent variable at a 5\% significance level using Pearson Correlation coefficients

\section{Correlation between Profitability and Liquidity}

Table 1: Correlations

\begin{tabular}{|c|c|c|c|}
\hline Variable & & Profitability & Liquidity \\
\hline \multirow{3}{*}{ Profitability } & Pearson Correlation & 1 & 0.733 \\
\hline & Sig. (2-tailed) & & 0 \\
\hline & $\mathrm{N}$ & 30 & 30 \\
\hline \multirow{3}{*}{ Liquidity } & Pearson Correlation & 0.733 & 1 \\
\hline & Sig. (2-tailed) & 0 & \\
\hline & $\mathrm{N}$ & 30 & 30 \\
\hline
\end{tabular}

According to Pearson Correlation the correlation coefficient was 0.733 with a $p$ value of 0.00 which is less than the level significance of $5 \%$ as shown by Table 1 above. This means that there is a strong positive correlation between profitability and liquidity.

\section{Correlation between Profitability and Size}

Table 2

\begin{tabular}{|c|c|c|c|}
\hline \multicolumn{4}{|c|}{ Correlations } \\
\hline Variable & & Profitability & Size \\
\hline \multirow{3}{*}{ Profitability } & Pearson Correlation & 1 & 0.81 \\
\hline & Sig. (2-tailed) & & 0 \\
\hline & $\mathrm{N}$ & 30 & 30 \\
\hline \multirow{3}{*}{ Size } & Pearson Correlation & 0.81 & 1 \\
\hline & Sig. (2-tailed) & 0 & \\
\hline & $\mathrm{N}$ & 30 & 30 \\
\hline
\end{tabular}

The Pearson Correlation coefficient was 0.810 with a $\mathrm{p}$ value of 0.00 . Since the $p$ value is less than the $5 \%$ level of significance it means there exist a strong positive correlation between profitability and size as shown in Table 2 above. 


\section{International Journal of Science and Research (IJSR) \\ ISSN (Online): 2319-7064}

Index Copernicus Value (2015): 78.96 | Impact Factor (2015): 6.391

$\begin{aligned} & \text { Correlation } \\
& \text { Opportunity }\end{aligned}$
\begin{tabular}{|c|c|c|c|}
\multicolumn{4}{c|}{ Table 3 } \\
\hline \multicolumn{4}{|c|}{ Correlations } \\
\hline Variable & & Profitability & G .Opportunity \\
\hline \multirow{3}{*}{ Profitability } & Pearson Correlation & 1 & 0.295 \\
\cline { 2 - 4 } & Sig. (2-tailed) & & 0.114 \\
\cline { 2 - 4 } & $\mathrm{N}$ & 30 & 30 \\
\hline \multirow{2}{*}{$\begin{array}{c}\text { G. } \\
\text { Opportunity }\end{array}$} & Pearson Correlation & 0.295 & 1 \\
\cline { 2 - 4 } & Sig. (2-tailed) & 0.114 & \\
\cline { 2 - 4 } & $\mathrm{N}$ & 30 & 30 \\
\hline
\end{tabular}

The Pearson Correlation coefficient is 0.29 with a $\mathrm{p}$ value of 0.11 which is less than $5 \%$ significance level. This means that there exists a relatively weak but positive correlation between profitability and growth opportunity.

\section{Test for significance of Regression Coefficients}

The coefficients of the independent variables were tested for significance at $5 \%$ level of significance using t-test.The results are summarised in the below. Unstandardized coefficients were considered since they indicate average change in the independent variable linked to one unit change in the dependent variable.

Table 4: Regression Coeffecients

\begin{tabular}{|l|l|c|c|c|c|}
\hline \multirow{2}{*}{ Variable } & \multicolumn{2}{|c|}{$\begin{array}{c}\text { Unstandardized } \\
\text { Coefficients }\end{array}$} & $\begin{array}{l}\text { Standardized } \\
\text { Coefficients }\end{array}$ & \multirow{2}{*}{ Sig. } \\
\cline { 2 - 5 } & B & Std. Error & Beta & \\
\hline \multirow{4}{*}{ Constant) } & -42.257 & 5.457 & & 0 \\
\hline Liq. & 9.415 & 4.818 & 0.306 & 0.062 \\
\hline G.O & -0.401 & 3.686 & -0.013 & 0.914 \\
\hline Size & 1.787 & 0.495 & 0.592 & 0.001 \\
\hline
\end{tabular}

a. Dependent Variable: Profitability

\section{Effect of Growth Opportunity on Profitability}

The study was based on the hypothesis that growth opportunity has no significant effect on profitability of firms. According to the t-test a unit decrease in growth opportunity will result to a 0.401 decrease in profitability. This means that Growth Opportunity has a negative effect on profitability. Growth opportunity which was measured using annual percentage change in total assets had a $p$ value of 0.914 as shown in Table 4 above. This is above the statistically significance level of 0.05 which led to the rejection of the null hypothesis that growth opportunity has no significant effect on profitability.

\section{Effect of Firm Size on Profitability}

The hypothesis that firm size has no significant effect on profitability was tested using t-test. According to Table 4 above a unit increase in firm size will result to a 1.787 increase in profitability. Firm size was measured using In of total assets and had a significant value of 0.01 which is below the 5\% significance level. This results to the rejection of the null hypothesis that firm size has no significant effect on profitability firms listed in the NSE.

\section{Effect of Liquidity on Profitability}

The hypothesis was also tested using t-test to determine whether to accept or reject the hypothesis. The Table 4 above shows that a unit increase in liquidity results to a 9.42 increase in profitability. Liquidity has a $p$ value of 0.62 which is above the statistically accepted significance level of $5 \%$.Thus, accepting the null hypothesis that liquidity has no significant effect on profitability of firms listed in the NSE.

\section{Regression Model Specification}

To carry out the causal-effect relationship between the variables regression model was used. Table 10 below shows a summary of the model specification.

Table 5

\begin{tabular}{|c|c|c|c|c|c|}
\hline \multicolumn{7}{|c|}{ Model Summary } \\
\hline Model & R & R Square & $\begin{array}{l}\text { Adjusted } \\
\text { R Square }\end{array}$ & $\begin{array}{l}\text { Std. Error of } \\
\text { the Estimate }\end{array}$ & $\begin{array}{c}\text { Durbin- } \\
\text { Watson }\end{array}$ \\
\hline 1 & 0.837 & 0.7 & 0.665 & 5.5584654 & 2.281 \\
\hline \multicolumn{7}{|c|}{ a. Predictors: (Constant), Liquidity, Growth Opportunity, } \\
Size \\
\hline \multicolumn{6}{|c|}{ b. Dependent Variable: Profitability } \\
\hline
\end{tabular}

From Table 5 above, the value of $\mathrm{R}^{2}$ is 0.700 meaning that $70 \%$ of the variation can be explained by the independent variable or accounted for in the dependent variable. The remaining $30 \%$ is attributed to other factors that are not within the control of the researcher. All the independent variables therefore affect profitability. Adjusted $\mathrm{R}^{2}$ explains variation in dependent variable due to changes in the independent variable. Thus the value 0.665 indicates that nearly $66.5 \%$ of changes in profitability of firms listed in the NSE is due to changes in liquidity, firm size and growth opportunity.

Table 6

\begin{tabular}{|c|c|c|c|c|c|}
\hline \multicolumn{6}{|c|}{ ANOVA } \\
\hline \multicolumn{2}{|c|}{ Model } & $\begin{array}{c}\text { Sum of } \\
\text { Squares }\end{array}$ & $\begin{array}{c}\text { Mean } \\
\text { Square }\end{array}$ & F & Sig. \\
\hline & Regression & 1.872 & 1.368 & 20.197 & 0 \\
\cline { 2 - 6 } & Residual & 0.803 & 0.896 & & \\
\cline { 2 - 6 } & Total & 2.675 & & & \\
\hline \multicolumn{6}{|c|}{ a. Predictors: (Constant), Liquidity, Growth Opportunity, Size } \\
\hline \multicolumn{6}{|c|}{ b. Dependent Variable: Profitability } \\
\hline
\end{tabular}

ANOVA was used to check whether liquidity, growth opportunity and firm size have a significant effect on profitability. From Table 6 above the p value is 0.000 (less than 0.05) this means removing any of the independent variables from the equation will affect the dependent variable.

\section{Regression Equation}

The following regression equation shows the relationship between the independent variables and the dependent variable.

$\mathrm{ROA}=-2.257+9.415 \mathrm{LQ}+1.787 \mathrm{FM}-0.401 \mathrm{GO}$

Where ROA=Return on Assets, $\mathrm{LQ}=$ Liquidity, FM= Firm Size, $\mathrm{GO}=$ Growth Opportunity.

The equation above means that holding liquidity, firm size and growth opportunity at a constant zero, the profitability of firms listed in the NSE will stand at -42.257 . According to the equation therefore, a unit increase in liquidity would result to an increase in profitability by a factor of 9.415 ; a unit increase in firm size would result to an increase in profitability by a factor of 1.787 and a unit increase in growth opportunity would result to a decrease in profitability

\section{Volume 6 Issue 7, July 2017}




\section{International Journal of Science and Research (IJSR) \\ ISSN (Online): 2319-7064 \\ Index Copernicus Value (2015): 78.96 | Impact Factor (2015): 6.391}

by a factor of 0.401 . The independent variables were tested for significance using t-test and the results shown in Table 9. Firm size showed a significant level of 0.01 which is less than the statistically accepted 0.05 whereas liquidity and growth opportunity both had $\mathrm{p}$ values above 0.05 . The error term value was expected to be zero and was thus not included in the equation.

\section{Conclusion}

The study concluded that financial leverage has an effect on the profitability of firms listed in the NSE especially firm size which had a $\mathrm{p}$ value that is less than the statistically accepted 0.05 level of significance. Firm size was measured using In of total assets. This conclusion concurs with the finding of Amar, Mohammad and Muhammad (2013) which concluded that financial leverage showed a positive effect on the profitability of banks in Pakistan. It is also in line with the Trade-off theory which argued that usage of debt has a positive effect on profitability when optimized. It is therefore important for the listed firms to control and manage their assets efficiently in order to increase their profitability.

Nevertheless, liquidity and growth opportunity were not statistically significant as there $\mathrm{p}$ values were more than 0.05 . This means that they both have no significant effect on the profitability of firms listed in the NSE. This is in agreement with the Modigliani and Miller Capital Irrelevance Theory according to which usage of debt in the capital structure of a firm has no effect on its profitability. It also concurs with the findings of Yego (2014) in Kenya which concluded that financial leverage has no significant effect on the profitability of banks in Kenya. Based on these findings, firms can therefore maintain minimum levels of liquidity as well as seek to increase assets that can be collateralized so as to improve their profitability

\section{References}

[1] Akhtar, S., Javed,B.,Maryam,H., \&Sadia,K.(2012). Relationship between financial leverage and financial performance: Evidence from Fuel and Energy Sector in Pakistan. European Journal of Business and Management, Vol.4, 11

[2] Ammar, A.G., Mohammad, Y.R., \& Muhammad, M.S. (2013). Impact of Capital Structure on Banking Performance: A Case Study of Pakistan. Interdisciplinary Journal of Contemporary Research in Business, VOL.4, 10

[3] Cooper, D.R, \& Schindler, D.S. (2008). Business Research Methods. Boston: McGraw Hill Irwin.

[4] Dare, F., \&Sola,O. (2010). Capital Structure and Corporate Perfomance in Nigeria Petroleum Industry Panel Data Analysis. Journal of Mathematics and Statistics: Science publications.

[5] Eljelly, A. (2004). Liquidity, Profitability trade-off, an empirical investigation in an emerging market. Internatinal Journal of Commerce and Management, 14(2), 48-61.

[6] Gitman, L.J. (2009).Principles of Managerial Finance. $\left(12^{\text {th }}\right.$ Ed).Addison Wesley: Prentice Hall.
[7] Jensen, M. (1986). Agency cost of free cash flow, corporate finance and takeovelrs. American Economic Review, Vol.76, 323-329.

[8] Modgliani, F., \& Miller, M.H. (1963). Corporate Income, Taxes and Cost of Capital: A Correction American Economic Review, Vol.53.

[9] Mugenda, M., \&Mugenda, G. (1999).Research Methods. Quantitative and Qualitative Approahes. Nairobi, Kenya

[10] Myers, B. (2003). Principles of Corporate Finance. $\left(7^{\text {th }}\right.$ Ed).McGraw-Hill Companies.

[11] Myers, C.S. (2001). Capital Structure P. Journal of Economic perspectives.14 (2).82- 102.

[12] Myers, C.S., \&Majluf, N.S. (1984). Corporate Financing and Investment Desions.

[13] Nduati, M. (2010). The Relationship between Leverage and Financial Performance of Companies quoted at the NSE. Unpublished MBA Project,University of Nairobi.

[14] Nairobi Securities Exchange, (2013). NSE Handbook. Nairobi Securities Exchange Information services.

[15] Osuji, C.C, \&Odita, A. (2012). Impact of Capital Structure on the Financial Performance of Nigerian firms. Arabian Journal of Business and Management Review, Vol.1, 12.

[16]Pandey, I.M. (2008). Financial Management.Vikas Publishing Hous PVT Limited: New Dheli.

[17] Pandey, I.M. (2004). Capital Structure, Profitability and Market Structure: Evidence from Malaysia. Asla Pacific Journal of Economics and Business, Vol.8, 12.

[18] Pouraghajan, A., \&Bagheri, M. (2012). The Relationship between Capital Structure and Firm Performance: Evidence from Tehran Stock Exchange: Internal Journal of Business and Commerce,1(9), 166181.

[19] Roger, H.H., James, D.E., \& Michael, W.M. (1998). Accounting Principles: Business Perspective, Financial Accounting. ( $8^{\text {th }}$ Ed).Irwin McGraw Hill.

[20] Yego, W.(2014).The Effect of Capital Structure on firms profitability: Evidence from Kenyan Banking Sector. Research Journal of Finance and Accounting, Vol.5, 9. 